\title{
Urban Hunters
}




\section{Eurasia Past and Present}

General Editors

Catriona Kelly

University of Oxford

Douglas Rogers

Yale University

Mark D. Steinberg

University of Illinois 


\section{Urban Hunters \\ Dealing and Dreaming in Times of Transition}

Lars Højer and Morten Axel Pedersen 
Published with assistance from the Mary Cady Tew Memorial Fund.

Copyright (C) 2019 by Yale University.

All rights reserved. This book may not be reproduced, in whole or in part, including illustrations, in any form (beyond that copying permitted by Sections 107 and 108 of the U.S. Copyright Law and except by reviewers for the public press), without written permission from the publishers.

Yale University Press books may be purchased in quantity for educational, business, or promotional use. For information, please e-mail sales.press@yale.edu (U.S. office) or sales@yaleup.co.uk (U.K. office).

Photographs are by the authors except as indicated.

Set in Adobe Garamond and ITC Stone Sans type by Newgen North America, Austin, Texas.

Printed in the United States of America.

Library of Congress Control Number: 2018962996

ISBN 978-0-300-I96II-5 (hardcover : alk. paper)

A catalogue record for this book is available from the British Library.

This paper meets the requirements of ANSI/NISO Z39.48-1992 (Permanence of Paper).

IO $98765432 \mathrm{I}$ 